


\title{
"O AMOR DOS COMEÇOS": POR UMA HISTÓRIA DAS RELAÇÕES COMA ESCOLA
}

\author{
DENICE BARBARA CATANI \\ BELMIRA A. O. BUENO \\ CYNTHIA P. DE SOUSA
}

Faculdade de Educação da Universidade de São Paulo - Feusp

\section{RESUMO}

Este texto explicita e discute peculiaridades das relações que os individuos, homens e muIheres (alunos e professores), mantêm com a escola e com as diferentes disciplinas e os significados dessas relações em histórias de escolarização, com base em depoimentos presentes na literatura, nas autobiografias e nos relatos de formação intelectual de alunos e professores já atuantes. Pretende-se, com a análise, propor novas modalidades de formação favoráveis ao conhecimentos e, assim, ultrapassar concepções de que essas relações são contaminadas por vagos atributos como o interesse ou o desinteresse dos alunos. RELAÇÕES ESCOLA-COMUNIDADE - RELAÇÕES ESCOLA-FAMILIA - RELAÇÕES PROFESSOR-ALUNO - ESCOLARIZAÇÃO

\begin{abstract}
"LOVE FOR BEGINNINGS": TOWARDS A HISTORY OF RELATIONSHIPS WITH THE SCHOOL. This article explains and discusses the particulars of the relationship men and women (students and teachers) maintain with the school and how the different disciplines and the meanings of these relations appear in their schooling histories. The information is based on reports in the literature, in autobiographies and in reports of the intellectual training of already active students and teachers. It intends, with analysis, to propose new ways of favorable training to knowledge and thus getting beyond conceptions that these relationships are contaminated by vague attributes, such as an interest or disinterest in students.

O Amor dos Começos é a expressão que dá título à autobiografia de J.B. Pontallis da qual se fala neste texto. Este texto integra uma série concebida com o objetivo de investigar os entrecruzamentos dos temas "Docência, Memória e Gênero" - Gedomge - e ancora-se em estudos e pesquisas desenvolvidos pelo grupo do mesmo nome, na Faculdade de Educação da USP.
\end{abstract}


Buscar explicitar e ressaltar a voz dos agentes envolvidos nos processos educacionais, escolarizados ou não, é um investimento que tem encontrado defensores tanto no território da história da educação quanto no domínio dos esforços para construir propostas de intervenção na formação. Antonio Nóvoa, no que diz respeito aos estudos históricos, ao referir-se a um trabalho de reinvenção das fontes que permita um aprofundamento da documentação já identificada e a descoberta de novos materiais de investigação, assinala:

As tradições orais, as publicações periódicas, as biografias e autobiografias, os relatos de vida escolar, a iconografia, os materiais didacticos, os cadernos escolares: eis algumas das entradas possíveis do trabalho historiográfico em educação, para além dos escritos dos educadores e dos pedagogos, recontextualizados na óptica da história cultural e intelectual. (Nóvoa, 1993, p. 19)

E, um pouco além, no mesmo texto, ao mencionar possíveis temáticas de investigação lembra: “...o quotidiano escolar, as práticas pedagógicas, os factores educativos (alunos, pais, professores), a educação de adultos, a educação colonial ... as práticas de leitura, os currículos etc." (idem, ibidem). Julgamos que tais observações são extensivas, no essencial - e pela multiplicação de possibilidades de conhecimento -, às tentativas que possam ser feitas para encontrar modos de explicações férteis para os processos de formação, a vida escolar e as relações com a escola, e daí fazer decorrer alternativas de intervenção nas práticas.

Pretende-se neste texto, com base em relatos autobiográficos', explicitar e discutir as peculiaridades das relações que os indivíduos, homens e mulheres (alunos e professores), mantêm com a escola e com as diferentes disciplinas, e os significados dessas relações em histórias de escolarização e na formação da identidade dos professores. Tal análise contribui para a proposição de novas modalidades de formação que estimulam disposições favoráveis ao conhecimento, ultrapassando formulações correntemente alimentadas pelos discursos de professores que, muitas vezes, vêem essas relações contaminadas por vagos atributos como o interesse ou o desinteresse dos alunos. É, portanto, ao buscar depoimentos na

I. Para a elaboração da análise foram examinados 22 relatos autobiográficos de professoras de Habilitação Magistério (curso de formação de docentes para as quatro primeiras séries do $1^{\circ}$ grau), outros 13, feitos por alunos de licenciatura (cursando ou já tendo cursado a Faculdade de História, Letras ou Artes Cênicas e, por esta razão, alguns deles já trabalhando como professores) e 53, produzidos por alunas do curso de Pedagogia. Os relatos dos alunos foram escritos no âmbito de cursos de Didática e o das professoras no âmbito de um trabalho de formação contínua. Os textos foram produzidos nos três últimos anos, no quadro de discussões acerca das significações de processos formadores. 
literatura, nas autobiografias e nos relatos de formação intelectual, de alunos e de professores já atuantes, que se tenta entender a diversidade das relações instauradas com a escola e com os conhecimentos em diferentes momentos da vida dos homens e das mulheres. Além disso, pretende-se analisar também a natureza das relações entre as experiências escolares iniciais e a identidade docente.

No livro em que narra suas memórias, intitulado O amor dos começos, Jean Baptiste Pontallis descreve, no primeiro capítulo, como se dá sua iniciação na escola e as conturbadas relações que experimenta com a linguagem, os professores e o conhecimento. Fala de um turbilhão que arrasta a criança de cinco anos, pela primeira vez levada à escola. As primeiras frases de seu livro expressam o significado dessa experiência: "Tenho que começar pelo curso H. É que vejo nele a origem dos meus tormentos, pelo menos do que será aqui meu objeto: o amor e o ódio pela linguagem...". Mais adiante, na mesma página: "Assim vou começar pelo curso H. Até então eu tinha sossego. Foi lá meu martírio". O autor evoca a sua vontade de não falar, do prazer infantil que experimentava em guardar silêncio e do sonho daquele tempo, que era escolher uma profissão na qual não fosse preciso quase falar. O psicanalista, autor de Vocabulário de psicanálise, reflete então:

E hoje, no entanto, toda a minha atividade profissional, que eu quis diversificada, diz respeito unicamente à linguagem: exerço a psicanálise, edito livros e uma revista, leio manuscritos, escrevo de vez em quando, às vezes traduzo. Eis-me assim, mais que a maioria, um homem ocupado, em terrenos diferentes, por um mesmo objeto: as palavras. (Pontallis, 1988, p. 13-14)

O primeiro capítulo do livro chama-se "O amor pelo colégio". Nele, seu autor mencionará também outro início que não o curso H: "As coisas mudaram radicalmente com a entrada no Lycée Pasteur...". E, mais adiante, refletindo sobre a infância, diz:

Há trechos inteiros que não suscitam em mim nem saudade nem emoção. Ou se nostalgia existe, ela é de uma natureza bem particular: é, tratando-se do colégio, a de um mundo fechado, ao mesmo tempo minuciosamente ordenado e, no interior deste fechamento, desta ordem, desta economia regulamentada, permeado por uma vida extraordinariamente aberta, móvel e múltipla... A diversidade, eu a encontrava tanto em nossos professores quanto em meus colegas... (p. 2l)

E, por fim, ao comparar o curso H e o colégio ele lembra que “ ...no colégio em vez de submeter-me às arbitrárias regras do jogo, eu via nessas regras um jogo..." (p. 26). Na história de Pontallis, a iniciação só se torna feliz quando ele 
encontra sentido no jogo dos comportamentos, da língua e do conhecimento, enfim, do mundo escolar, e atinge o apogeu quando ele se vê capaz de compreender a lógica da disciplina e das disciplinas na escola.

É num antigo texto do professor londrino R.S. Peters que encontramos explicitada a idéia do processo educacional como um processo de iniciação. De fato, no próprio título de seu artigo isso já está expresso: "Educação como iniciação" (1979). Também, nesse artigo se lê que a educação

...consiste em iniciar os outros em atividades, modos de conduta e pensamento, que possuem regras intrínsecas, referentes ao que é possível para a ação, para o pensamento e para o sentimento, nos vários graus de competência, relevância e gosto. (p. 125)

No decorrer do texto, o autor mostra que a idéia e o termo iniciação são capazes de abrigar vários tipos de atividades, contando sempre com o fato de que, como processo, essa iniciação supõe atividades e modos de conduta valiosos. Pensa o autor que iniciar alguém numa dada área de conhecimento é, antes de tudo, familiarizá-lo com as regras que organizam esse conhecimento, com a linguagem e com os argumentos que lhe são próprios. Para Peters, um processo de iniciação, no sentido por ele atribuído ao termo, deve ter como principal conseqüência a geração de disposições férteis para com as várias áreas, comportamentos ou valores envolvidos na educação. A história das relações ou disposições férteis mantidas pelos indivíduos para com as diversas disciplinas é decerto um elemento importante para se compreender êxitos e fracassos no processo de escolarização dos indivíduos.

Uma compreensão fértil das significações da educação escolar, de um ponto de vista histórico ou de um ponto de vista contemporâneo, em nosso entender, deve incluir uma história das relações que a escola tem propiciado aos indivíduos, com ela própria e com os objetos que constituem suas finalidades: o conhecimento, a leitura, a escrita, a disciplina, por exemplo. De fato, a sugestão inicial para essa forma de propor a questão vem de Peters, com o privilégio atribuído às disposições que se devem favorecer no ensino. Uma grande profusão de referências às relações ou disposições desse gênero é encontrável principalmente na literatura de caráter autobiográfico e nas obras memorialísticas. Nas menções feitas aos significados que a escola assume para os indivíduos que relatam suas histórias de formação, é freqüente a inclusão de lembranças dos inícios na escola e de suas ressonâncias.

De que modo meninas e meninos, na sua infância, desenvolveram suas experiências iniciais com o meio escolar? Quais foram os sentimentos rememorados 
dos primeiros tempos na escola e quais as marcas que ficaram dessa experiência: prazer, desprazer, conforto, desconforto, alegria, choro; os meninos gostaram, as meninas choraram? Ou vice-versa? A escola, inicialmente, seduz, repele ou combina os dois sentimentos? Será que existe, ainda, algum estereótipo definidor de comportamentos, nesse tipo de experiência, para homens e para mulheres? A partir do exame das narrativas é possível indicar alguns temas recorrentes que constituem as marcas deixadas pelas primeiras experiências na vida escolar. A maioria das narrativas, de forma mais ou menos independente da idade das autoras e dos autores, conserva um tom nostálgico. O fato de trabalhar com os textos obrigou-nos a considerar o significado da escrita para os indivíduos que reconstroem suas experiências de escolarização e de relações com o conhecimento. No texto: "Être soi: écritures ordinaires de l'identité", Jean Pierre Albert auxilia-nos a compreender que "a escrita supõe um processo de expressão de objetivação do pensamento que explica sua aptidão para reforçar ou constituir a consciência de si de quem escreve". Diz ainda: "A escrita aparece assim como um meio privilegiado de tomada de consciência, ela nos dá nosso próprio pensamento, em sua forma mais elaborada" (1995, p. 46). Ele lembra, ainda, como isso ocorre, também, quando nos tomamos a nós mesmos como objeto dessa experiência reflexiva, de escrever sobre si. Adverte ainda sobre os riscos de se iludir quanto ao conhecimento que advém desses meios, nos quais e com os quais o indivíduo constrói uma imagem aceitável aos seus próprios olhos e aos dos outros. Sem nos estendermos sobre essa questão, aliás já analisada por outros estudiosos, podemos dizer que, estando atentas a tais implicações, as utilizamos como objeto de estudo também no trabalho de formação docente? ${ }^{2}$.

As incursões interpretativas dos textos têm-nos levado a observar muitas peculiaridades da relação com a escola e é isto que examinamos a seguir.

\section{A ESPERA PELA ENTRADA NA ESCOLA OU "A ANSIEDADE VIRANDO AGONIA"}

A existência de irmãos, irmãs, primos e primas mais velhos experimentando a vida na escola é, reiteradamente, apontada nos relatos como algo que aguçou a curiosidade, ou que começou a fazer parte do universo infantil por conta da perda temporária dos parceiros de brincadeiras e o conseqüente sentimento de solidão. Ou, ainda, pelo fato de a mãe ser professora ou de um ou outro caso em que pai e mãe eram professores e o assunto escola/estudo estar sempre presente no

2. Entre os trabalhos que, sistematicamente, analisaram as implicações e o alcance do uso de textos autobiográficos, de uso especificamente no que diz respeito à educação, devem-se mencionar: Nóvoa, Finger ( 1988); Josso (1991). 
ambiente familiar. A "inveja" (termo mais utilizado pelas mulheres) da situação vivida pelo outro, a visão de crianças uniformizadas passando pela rua, o convívio com irmãos e outros parentes na hora das lições de casa são alguns dos motivos que aparecem simultaneamente à menção do desejo de também partilhar da experiência de freqüentar a escola.

Excertos de dois relatos evidenciam o que está sendo dito:

Meus irmãos mais velhos estavam há três anos, dois anos e um ano na escola quando chegou a minha vez. Finalmente eu teria uma mochila cheia de materiais maravilhosos: lápis colorido, canetinhas, livros cheios de desenhos. E eu também aprenderia a ler e a escrever e poderia ler placas e rótulos como meus irmãos compulsivamente faziam. Eu estava assim ansiosa ao lado de minha mãe, a caminho da escola (...) meu entusiasmo transformou-se na primeira grande frustração... minha matrícula não foi aceita pois eu só completaria 7 anos depois de julho. (Relato de uma aluna)

Aguardando ansiosamente por mais um ano, essa aluna da licenciatura conta ainda do mistério que ela pressentia nas palavras usadas por seus irmãos:

Prova, professora, carteira, cada uma dessas palavras bizarras suscitava em minha cabeça interpretações estranhíssimas. Quando finalmente ingressei na escola, a realidade superou magnificamente minha imaginação. Havia tanto para ver, tanto para aprender, tantas crianças tão diferentes, tantas novidades... (Idem)

Sobre essa expectativa que nos relatos aparece, às vezes, descrita como insuportável e as significações que se vão atribuindo à escola, outra aluna da licenciatura diz:

Não sei ao certo quando foi o meu primeiro dia de aula, nem do que aprendi então, mas vejo-me admirar minha irmã, vestida com aquele mesmo avental xadrez azul e branco que mais tarde usaria ao entrar na escola. Eu só não entendia aquele ritual matutino diário: minha mãe ao acordar minha irmã, colocava por sobre a cama o avental limpo e fresco, pronto para selar sua partida naquele ônibus repleto de outros aventais. E eu então me enfurecia, ao ver que minhas roupas nada tinham daquele xadrez celeste e que eu não carregava lancheira no ombro (...) Quando realmente ingressei na escola, eu não estava mais tão entusiasmada, eu talvez até chorasse ao me despedir de minha mãe toda manhã, como fazia a maioria das crianças presentes no ônibus. (Relato de uma aluna)

Outro relato, também de aluno do mesmo curso, ressalta:

Talvez eu achasse a escola um lugar fascinante (dá para ver que eu era muito ingênuo), talvez eu tivesse entre 3 e 5 anos. A escola era o lugar onde eu via os 
garotos irem todo dia e onde eu não podia ir (...). Certo dia me cansei, peguei uma bolsa velha de minha mãe, enchi de revistinhas - afinal na escola a gente leva livros - ah, sim, na escola você leva lanche, por isso pus nela meu hipopótamo amarelo de plástico, meu leãozinho vermelho e o leopardo verde, todos também de plástico, e lá fui eu para a escola. Encontrei os portões fechados (...) um balde de água gelada. Meio decepcionado peguei o caminho para casa, estava com fome, e já estava quase devorando o hipopótamo amarelo quando cruzei com mamãe, ela estava afogueada, tinha dado falta de mim e veio correndo me procurar - depois soube que tinha sido denunciado por uma vizinha. (Relato de um aluno)

Parte desse "desejo" ou dessa "fascinação" pela escola pode muito bem ter sido estimulada por mães, pais, irmãos e irmãs que se fizeram de mestres e mestras e introduziram as crianças (obtendo bons ou maus resultados do ponto de vista da aprendizagem) no mundo do alfabeto e dos números. $\bigcirc$ fato é que mais de $50 \%$ dos 88 relatos retratam esse desejo de ir à escola e o grande significado atribuído às atividades ligadas a ela. Muitas vezes, porém, a nova realidade com a qual esses meninos e meninas tiveram que conviver mostrou-se bastante diferente daquilo que foi vivido durante os "preparativos" domésticos para a entrada na escola ou, ainda mesmo, quando tal preparação não ocorreu.

Minha mãe tentou introduzir-me nas letras quando eu tinha três anos, aproximadamente, era tudo o que eu mais queria, ou achava que queria pois, no primeiro dia de aula, tão logo fui entregue à professora, fugi, para desespero de todos. Vaguei horas pelas ruas mas, mais uma vez, os astros estavam a meu favor, fui localizada... (Relato de uma professora)

Se nos reportarmos às passagens que descrevem as experiências vividas na época da meninice e da adolescência, existentes em obras da literatura brasileira, as quais apenas recentemente têm sido tomadas como objeto de estudo e de reflexão na constituição de uma história da infância e da família no Brasil, podemos encontrar uma gama de histórias carregadas de sentimentos conflitantes e que podem servir de contraponto ou reforço às imagens e representações vividas pelas pessoas, com as quais temos trabalhado. Além do mais, essas obras literárias, por trazerem rememorações dos tempos escolares, vêm servindo também como uma das fontes possíveis para a pesquisa em História da Educação Brasileira. Nesse sentido, sua utilização em alguns dos cursos de História da Educação, ministrados na Feusp, tem despertado um interesse vivo e produtivo, revelado tanto nas discussões, quanto nos trabalhos realizados por alunas e alunos de nossa graduação. 
O texto memorialístico escrito por João Lourenço Rodrigues, um educador da virada do século, é exemplar no sentido de construir uma versão da história dos fatos da educação em São Paulo. Esse livro tem sido, inúmeras vezes, tomado como fonte para a história educacional do período 3 . É bastante interessante observar, ao lado de seu esforço para sistematizar documentos e acontecimentos, a narrativa dos episódios mais significativos que o autor viveu. A propósito de sua entrada na escola, ele também dedica algumas páginas, rememorando essas experiências escolares no livro:

Foi em 1875 que eu, tendo pouco mais de 6 annos me matriculei na escola do Professor Pires (...) Escassas lembranças me ficaram desse dia já tão distante. Lembro-me, contudo, ainda agora, que não tinha o ânimo muito tranqüilo quando, ao lado de meu pai, seguia pela primeira vez em demanda da escola. Obsedava-me por certo o fantasma da palmatória, pois ouvira dizer que o mestre ensinava bem, mas era bravo e dava bolos sem dó nem piedade... (1930, p. 46)

Após narrar a entrada na classe, a figura do professor, o início das atividades e suas aflições com as vogais, lembra que uma borboleta invadiu a sala, todos silenciaram observando-a e o autor diz: "Que vontade tive de seguil-a para ir correr à sombra dos laranjais! Aquela imobilidade tão fora de meus hábitos me torturava" (p. 50).

Depois de tentar sair atrás da borboleta e ter de voltar ao lugar, a mando do professor, foi tomado de torpor, bocejou e sentiu que a escola começou a the parecer terrivelmente enfadonha: "Por fim, não me contive mais e, num movimento impulsivo, levantei-me e arrojei-me porta afóra, numa corrida desabalada" (p. 5I). Hoje, um aluno da licenciatura, ao construir um relato que intitula de "Iniciação escolar", afirma:

Ao entrar para o primeiro ano primário, as coisas começaram a ficar mais sérias, lembro de um colega de nome Humberto, que chorou demais, não queria ficar na escola e ao primeiro descuido da professora saiu pela janela, mas como era um pouco alta para pular para o lado de fora, na sua demora foi seguro e aos berros foi puxado para dentro da sala novamente. (Relato de um aluno)

São sentimentos conflitantes como os descritos acima que nos fazem recordar, por exemplo, de páginas lidas em Graciliano Ramos. Infânciaé um livro de memórias dos seus tempos de menino, publicado pela primeira vez em 1945, no Rio de Janeiro. 0 relato de suas experiências é carregado de imagens e sentimentos fortes, que começam

3. Sobre o confronto desse texto com outros, também produzidos no período por outros educadores, e o papel desses textos na sagração de uma versão da história, ver: Catani (1995). 
com apreensão, passam pelo medo e transformam-se em verdadeiro terror. Seu pai, comerciante de ferragens e miudezas em uma vila, vendo seu interesse em caixas, pacotes e em uns cadernos, perguntou-lhe se não queria aprender a ler o que estava escrito naqueles folhetos.

Meu pai tentou avivar-me a curiosidade valorizando com energia as linhas mal impressas, falhadas, antipáticas. Afirmou que as pessoas familiarizadas com ela dispunham de armas terríveis. Isto me pareceu absurdo: os traços insignificantes não tinham feição perigosa de armas. (p. 104)

Surpreso com a pergunta, incrédulo quanto ao poder de que estaria investido caso pudesse decifrar as letras e temeroso de contrariar o pai, aceitou a oferta e "a aprendizagem começou ali mesmo", como também seu inferno pessoal.

Meu pai não tinha vocação para o ensino, mas quis meter-me o alfabeto na cabeça. Resisti, ele teimou - e o resultado foi um desastre. Cedo revelou impaciência e assustou-me. (p. 106)

A mãe e uma das irmãs livraram-no, temporariamente, do tormento paterno, mas continuaram as tentativas de ensiná-lo. Para ele, "o sono era forte, enjôo enorme tapava-me os ouvidos, prendia-me a fala". Mas conseguiu "familiarizar-se" com as letras do alfabeto, depois de muitos sofrimentos, castigos, dificuldades e emudecimentos em presença do pai, sempre aos gritos para as lições do dia. Finalmente, o pai desistiu de ensiná-lo. Parecia que o tinham deixado sossegado para poder brincar no quintal, na rua, com os amigos; entretanto, outras coisas estavam por vir.

A notícia veio de supetão: iam meter-me na escola. Já me haviam falado nisso, em horas de zanga, mas nunca me convencera de que realizassem a ameaça. A escola, segundo informações dignas de crédito, era um lugar para onde se enviavam as crianças rebeldes. Eu me comportava direito: encolhido e morno, deslizava como sombra. As minhas brincadeiras eram silenciosas. (...) A escola era horrível - e eu não podia negá-la, como negara o inferno. Considerei a resolução de meus pais uma injustiça. (p. I 13-4)

O clássico de Raul Pompéia O Ateneu é um caso de obra memorialística que não se pode deixar de mencionar, pela sua recente redescoberta, na análise de Leyla Perrone Moisés (1988). Raul Pompéia trata das experiências do menino Sérgio, no Rio de Janeiro, àquela época Município da Corte, quando seu pai resolve matriculá-lo, aos dez anos, no internato de um colégio, cujo nome serve de título ao livro. Publicado pela primeira vez em 1888, o livro é um romance autobi- 
ográfico, "uma amarga crônica de saudades", da passagem escolar do autor pelo Colégio $\mathrm{Abílio}^{4}$. Antes, porém, de ser colocado como aluno interno, o menino Sérgio já tinha estudado em casa de "algumas senhoras inglesas" e, depois, com um professor particular, "a domicílio".

Apesar deste ensaio da vida escolar a que me sujeitou a família, antes da verdadeira provação, eu estava perfeitamente virgem para as sensações novas da nova fase. $\bigcirc$ internato! Destacada do conchego placentário da dieta caseira, vinha próximo o momento de se definir minha individualidade. Amarguei por antecipação o adeus às primeiras alegrias; olhei triste os meus brinquedos, antigos, já! (Pompéia, 1973, p. 26)

Um aluno da licenciatura reproduz um pouco essa sensação, sem ter o livro de Raul Pompéia em mente, ao escrever:

Quando me colocaram em uma escola: um "jardim-da-infância", percebi que havia envelhecido um pouco, pois me tiraram bastante da minha liberdade de ir, de vir (...). Foi um choque, que logo deve ter sido assimilado, pois devo ter acreditado na necessidade da escola e também que seria algo irreversível. (Relato de um aluno)

Um relato feminino, embora sem preocupações centrais com a vida escolar, é o de Zélia Gattai no seu livro Anarquistas, graças a Deus, publicado pela primeira vez em 1979, no Rio de Janeiro. A entrada para a escola deveu-se à interferência de uma professora leiga, vizinha da família Gattai:

Eu estava com quase oito anos; havia aprendido todas as letras do alfabeto assistindo às aulas de Wanda à Maria Negra, andava sempre com "O Estado de São Paulo" em punho, perguntando coisas a um e a outro. Lia frases inteiras. - Já está na hora mamãe dizia e repetia. - Já passou até da hora. Dona Carolina [a professora leiga] mandou um recado ontem, quer saber se vamos deixar a menina continuar analfabeta para o resto da vida. Fiquei até sem jeito! Vizinhos antigos, sempre mantivemos com a família Bulcão relações cordiais. Agora aquele recado, meio desaforado, de dona Carolina havia baratinado mamãe. Realmente, ela não tinha pensado que passara o tempo de matricular sua filha na escola. A menina era tão sabida, aprendia com facilidade, sem ninguém ensinar... Quanto mais tarde fosse à escola, melhor: menos tempo de escravidão entre quatro paredes, de humilhações e castigos corporais aplicados pelas professoras, hábito na época: bolos nas mãos, puxões de orelhas, joelhos sobre grãos de milho ou de feijão atrás da porta (...) meus pais acreditavam na escola da vida. A única que haviam cursado. Talvez por isso eu atingia

4. Sobre a história da educação no período, ver Haidar ( 1972 ). 
A entrada na escola transcorreu sem problemas. Dona Carolina era uma professora alegre, "nem feia, nem bonita", cujas aulas eram movidas a muita conversa, piadas e comentários de casos policiais estampados nos jornais: "(...) tomava partido, inflamavase. O tempo tornava-se escasso para o estudo propriamente dito" (idem, p. I89). Mas as histórias dos castigos corporais existentes nas escolas ficaram reduzidas ao uso da régua para a manutenção da disciplina:

...mantinha sobre a mesa pelo menos uma dezena de réguas, todas enfileiradas que atirava na cabeça da criança faltosa, com uma técnica muito especial: segurava numa das pontas da régua, fazia pontaria e... jamais errava o alvo. (Gattai, 1989, p. 189)

Isso foi pelos idos de 1924, portanto, há mais de 70 anos. Muitos dos sustos, medos, angústias, terrores, contidos nos relatos, tanto de professoras quanto de professores, devem-se a tentativas como essas, explícitas ou mais veladas, mas igualmente humilhantes, de imposição da disciplina, do respeito e da autoridade. Uma das professoras, cujo relato foi produzido no trabalho de formação contínua, conta sua mudança para outro sítio na zona rural, o que determinou a mudança de escola:

...a professora era terrível, quando os alunos não sabiam a tabuada, ela quebrava a régua de madeira na cabeça deles e dava beliscões, a unha bem grande não sai da minha cabeça. Em mim ela não batia porque almoçava em minha casa e eu também estudava para que nada me acontecesse. (Relato de uma professora)

Em outro relato, também de uma professora, a rudeza era paralisante:

No quarto ano meu professor se chamava Sr. Gabriel. Era gordo, careca, muito bravo, gritava tanto que tínhamos medo até de respirar mais alto. Minha vida era pensar "Graças a Deus" era o último ano e tudo ia acabar bem. (Relato de uma professora)

Neste outro relato, de um professor, fica claro que a agressão física era parte do conteúdo das aulas:

Dos professores do antigo primário pouco retive, exceto de um, famoso pela violência contra alunos, que the custou o posto naquela escola, removido a pedido de um movimento de mães. Ele simplesmente mandava que nos sentássemos e então passava pelas fileiras dando tapas nas costas e puxões de orelhas em todos os alunos. (Relato de um professor) 
Em um dos relatos de mulheres, lê-se o caso de uma certa professora, "horrorosa, tanto fisicamente, quanto espiritualmente", que lecionava inglês e música, e dirigia, durante as lições, agressões verbais com o objetivo de humilhar as alunas, trazendo resultados, talvez, piores do que a agressão física, por conta de sua durabilidade ao longo da vida:

Pela mínima coisa que fizéssemos, ela nos deixava a "zero". Era a única professora que quando entrava na sala, tínhamos que levantar. Nós, os alunos, não a respeitávamos: tínhamos era medo, pavor dela. (...) Quanto mais eu gaguejava, mais ela me xingava e mais nervosa eu ficava. Não consegui falar e as lágrimas escorreram pelo meu rosto de medo da professora e vergonha dos colegas. (Relato de um professor)

É necessário frisar, entretanto, alguns casos nos quais as primeiras experiências com a escola nem sempre foram desastrosas, mas foram rememoradas de modo positivo, desde o sentimento de que "tudo era como eu esperava" até formas de deslumbramento.

Quando criança, eu ia às escolas de meus pais (levado por eles) e sentia-me o dono daquele espaço, na medida em que meus pais eram seus professores. (...) $\bigcirc$ fato de ser professor fazia de meus pais, para mim, as pessoas mais importantes dentro daquela instituição. Talvez venha daí o interesse em ir à escola (...) (Relato de um professor)

Quando completei cinco anos entrei na escola e foi uma das minhas maiores realizações. A escola talvez fosse tudo que eu imaginava, pois me adaptei fácil e não aceitava a idéia de faltar. (Relato de uma professora)

A sedução exercida pelo uniforme e pelo material escolar, por exemplo, aparece vivamente em muitos dos relatos das professoras:

Via as crianças passarem uniformizadas e com material escolar. Que inveja sentia... Que vontade de ir à escola. Mas eu só tinha quatro anos... (Relato de uma professora)

Entrar na escola era um sonho. Tudo o que eu mais queria era poder usar aquele uniforme: saia pregueada azul-marinho, meia branca 3/4, sapato preto e fita branca nos cabelos. Achava maravilhoso e ficava horas e horas me olhando no espelho, rodava pra lá e pra cá, me sentia uma princesa. (Relato de uma professora)

Entretanto, entre os rapazes, esse detalhe é pouco ou nada relevante. Em poucos relatos aparece uma descrição do modo de se vestir para ir à escola: 
No relato de um aluno da licenciatura há as seguintes referências:

Usava um calção pequeno e vermelho e uma camiseta branca. Foi com estes trajes que comecei minha jornada na escola, jornada esta que duraria muito e que ainda não acabou. (Relato de um aluno)

Em outro relato, a lembrança do primeiro dia de aula:

Usava um uniforme que era tênis e calção azul e camiseta branca, mais uma mochila de pano, não me lembro o nome específico, que se fecha puxando dois cordões e empurrando a abertura dessa mochila que também era azul e tinha meu nome bordado em branco. (Relato de um professor)

\section{AS “MARCAS”, DE TODOS OS TIPOS, DEIXADAS PELOS ANTIGOS MESTRES}

Quanto aos professores e professoras "marcantes", vale alguma reflexão sobre o termo. Talvez se possa entender que ele signifique qualidade positiva, em que pese o fato de ter sido explicado aos autores e autoras das autobiografias que tais professores não seriam tão-somente os bons ou ruins. Mas foi um professor quem buscou, no seu relato, uma definição mais precisa para este adjetivo:

Falar dos professores mais marcantes, no meu entender, seria relatar apenas uma experiência que alterou, de modo profundo, o rumo de minha vida e que alterou, completamente, o rumo de minhas atitudes para com o mundo, com os Homens e com o meio, com o passado, o presente, o futuro e, enfim, com os outros professores. A proposta desse professor não era que os alunos pensassem como ele. Muito pelo contrário. Na aula, ou no contato particular, o aluno é despertado para que, por si só, descubra a sua forma de atuação e percepção, tanto profissional como pessoal e afetiva. (...) Os outros professores que passaram pela minha vida, todos, tornaram-se marcantes, positiva ou negativamente, através de suas crenças, dogmas ou caricaturas que, mais ou menos, revelaram em suas aulas. (...) Estas representações do mundo, lançadas em aulas diversas, do primário até a faculdade, foram sempre colocadas, com raras exceções, de maneira enfática e absoluta.

Os relatos evidenciam exatamente isto: lições aprendidas ou por aprender e mágoas ainda não superadas. Mais ainda: um sinal muito evidente de que professoras e professores atenciosos, compreensivos, humanos, mas nem por isso permissivos, com domínio de sua disciplina e com controle sobre a classe transmitiram segurança e confiança aos seus alunos, seja ao longo das séries iniciais, seja nas 
outras etapas de mudança do ciclo de vida escolar - na passagem para a 5a série, para o 2 grau e para o ensino superior. Alguns elementos presentes na forma de ser professor vão mostrar-se articulados a experiências escolares iniciais, conforme explicitamos a seguir.

\section{A FORMAÇÃO DA IDENTIDADE DOCENTE E AS EXPERIÊNCIAS ESCOLARES INICIAIS}

No âmbito do discurso sobre formação de professores o tema da identidade profissional é questão que deve ser mais problematizada. De um lado, em muitos casos, predomina a idéia de que a escolha da profissão docente é determinada por características pessoais inatas, e que a formação profissional acha-se circunscrita ao tempo e às práticas dos cursos de magistério. Alguns entendem que são esses cursos que dão a formação necessária àqueles que se destinam a ser professores e é ali, portanto, que eles devem firmar a identidade que já possuem "por vocação". De outro lado, à medida que as expectativas em relação a esses cursos se vêem frustradas, toma lugar a idéia de que as habilidades pedagógicas do professor são o produto e a conseqüência direta de suas experiências em sala de aula. E, assim sendo, conclui-se que os cursos e o que neles se ensina de muito pouco valem ${ }^{5}$. Para além das insatisfações muitas vezes procedentes, o que as críticas e acusações manifestam é muito mais do que isso. Trata-se, na verdade, de um modo de conceber a formação da identidade docente, que subestima e mesmo ignora, nesse processo, o papel das experiências escolares anteriores e as possíveis relações que essas mantêm com as experiências profissionais que têm lugar após o término dos cursos. Assim, é de fundamental importância rever essa concepção, uma vez que é sobre ela que se estrutura todo e qualquer trabalho destinado à formação de professores.

Tal como na primeira parte do texto, examinamos aqui narrativas que recuperam as relações com a entrada na escola e com o que nela se passa. Cabe agora examinar algumas relações entre as experiências escolares iniciais e o processo de formação da identidade docente, a partir do conteúdo de narrativas autobiográficas produzidas por professoras que trabalham conosco no projeto de educação continuada. Trata-se de um foco de análise que vem despertando interesse cada vez maior por parte dos pesquisadores ${ }^{6}$, cujos trabalhos, ainda que examinem essa rela-

5. São numerosos os trabalhos que apontam a presença de uma visão dicotômica entre os professores, que ora supervaloriza a teoria, ora a prática. Na tentativa de ir um pouco além, temos desenvolvido algumas análises que buscam compreender a natureza e algumas origens dessa visão. A esse respeito, ver: Bueno et al. (I993, p. 299-3 I 8), Bueno (I996, cap. 3, item 3.2.). 
ção sob diferentes prismas, convergem no sentido de mostrar que muitos dos aspectos envolvidos nas imagens e representações sobre o professor estão enraizados nas experiências infantis e na cultura do ensino, forjadas, especialmente, no contato e na convivência dos indivíduos com a própria escola. Diferentemente do que se poderia supor, tais experiências não desaparecem da história do sujeito. Embora pouco visíveis, pode-se dizer que, de algum modo, permanecem vivas e atuantes ao longo da formação, dando suporte às relações que paulatinamente o aluno, mais tarde, professor, acaba por estabelecer com a escola e com o conhecimento ao longo da vida. Supõe-se por isso que tais experiências são, em grande parte, articuladas à escolha profissional, e, na qualidade de elementos que permanecem subjacentes no processo de formação intelectual, atuam como modeladores das práticas pedagógicas que são levadas a efeito pelos professores. Desse modo, as experiências que têm lugar no início da escolarização, ao alicerçarem os desenvolvimentos ulteriores do indivíduo, cumprem um papel crucial na formação docente, mediante as imagens que se vão formando sobre o professor como profissional e sobre a escola como instituição social. Todavia, como se disse, por se mostrarem pouco perceptíveis nos modos de atuação do sujeito, tais experiências são ignoradas quanto ao papel que desempenham na dinâmica dos processos mediante os quais o professor constrói a sua identidade profissional.

Nós compartilhamos da convicção de Sandra Weber e Claudia Mitchell ( 1996 ) de que o estudo das imagens incorporadas desde a infância sobre o professor e o ensino propicia melhor compreensão acerca do desenvolvimento profissional, podendo resultar numa intervenção mais efetiva no tocante à percepção da sociedade sobre o trabalho docente. Além disso, enfatizamos também a importância de examinar as experiências que possivelmente estão em conexão com essas imagens, especialmente aquelas que desencadearam imagens ideais de mestres e favoreceram o caminho em direção à profissão docente. Esse tipo de estudo, potencializado pela análise dos relatos autobiográficos, parece contribuir de modo mais eficaz para deslocar o eixo tradicional das práticas de formação de professores, de acentuada orientação prescritiva, para modalidades de autoformação que ajudem o professor a exercer a crítica sobre o ensino e a encontrar em sua própria história possíveis nexos entre suas formas de conceber, de atuar e de se ver em relação ao trabalho docente.

Enfrentar a questão traz uma série de obstáculos, pois a própria palavra

6. A este respeito, mencionamos aqui alguns trabalhos: Weber e Mitchell (1996, p. 109-26), Sousa, et al. (1996, p. 61-76), Bueno (1996). Ainda que em perspectiva diversa da que estamos propondo, é oportuno indicar também o trabalho de Stephen Ball ( 1989). 
identidade pode, ilusoriamente, levar a supor a existência de um eumonolítico, construído no percurso de uma história linear, e que para ser identificado depende apenas de o sujeito acionar sua memória. Esta, por sua vez, é entendida, por alguns, como um arquivo de lembranças do passado meticulosamente ordenadas. Os desenvolvimentos teóricos que vêm sendo acumulados em diversas áreas, das ciências sociais às neurociências, mostram que tais processos se caracterizam por uma complexidade muito maior ${ }^{7}$. Tendo em vista a questão que nos interessa, convém ressaltar alguns aspectos que dizem respeito às relações entre memória e identidade e que se fazem presentes no trabalho com as narrativas autobiográficas. Assim, algumas questões podem ser sugeridas. De que modo as professoras se identificam em seus relatos? Quais são os primeiros eus que aí aparecem? De que modo são lembrados e reconstruídos por elas, especialmente, em relação à fase inicial da escolarização? E em que sentido as lembranças desse período se mostram, de alguma maneira, relacionadas a um percurso de formação da identidade docente? As considerações feitas a seguir tentam esboçar algumas respostas a essas questões.

\section{IDENTIDADE, MEMÓRIAS DE INFÂNCIA E NARRATIVA AUTOBIOGRÁFICA}

É quase impossível falar de identidade e memórias da infância sem lembrar de Lewis Carrol. O autor, ao brincar com a fantasia infantil, mostrou que sair da superfície e tentar responder "quem sou eu?" não é tarefa tão simples. O cenário privilegiado por Carrol é o "país das maravilhas", o poço no qual Alice, a menina curiosa, embrenha-se e envolve-se em sucessivas aventuras. A linguagem é a dos jogos de palavras e da dualidade de sentidos que o escritor faz proliferar indefinidamente (Leite, 1980). Com esses recursos e o apelo à fantasia, ele retrata de forma simples, mas angustiante, os paradoxos da identidade. Em suas aventuras, Alice depara várias vezes com a tarefa de ter que responder a si mesma ou a outrem quem ela é. E ainda que recorra com insistência à memória, vê-se quase sempre mal-sucedida, porque fica presa nas armadilhas de seu próprio discurso, como podemos ver, por exemplo, na cena em que se encontra com a lagarta:

7. Para se ter uma idéia da multiplicidade de abordagens que várias disciplinas têm dado sobre a questão da memória, indicamos a título de exemplo o volume temático da revista Psicología USP, organizado por César Ades. Esse volume inclui um de nossos trabalhos, já citado, no qual procuramos discutir, entre outros aspectos, a natureza individual e coletiva da memória e seu caráter dinâmico, que implica um trabalho de contínua construção e reconstrução do passado a partir de problemáticas do presente (Bueno, 1993). Com relação à identidade, basta lembrar que este tem sido um dos temas mais recorrentes na filosofia e também incorporado pela psicologia. 
A Lagarta e Alice olharam-se por algum tempo em silêncio. Finalmente, a Lagarta tirou o narquilé da boca e perguntou, em voz lânguida e sonolenta:

- Quem é você?

Não era um começo de conversa muito animador. Um pouco tímida, Alice respondeu:

- Eu... eu... nem eu mesmo sei, senhora, nesse momento... eu... enfim, sei quem eu era, quando me levantei hoje de manhã, mas acho que já me transformei várias vezes desde então.

- Que é que você quer dizer com isso? - perguntou a Lagarta, rispidamente.

- Explique-se!

- Acho que eu mesma não posso explicar - disse Alice - porque eu não sou eu, está vendo? (Carrol, 1980, p. 69, grifos do autor)

A perplexidade diante do ambíguo e do contraditório não é apenas o que caracteriza as reações de Alice. As mudanças que the ocorrem no fundo do poço levam-na a experimentar profunda angústia e, não raro, o desespero. A menina busca a si mesma nas profundezas, mas por ter perdido o contato com os outros não consegue saber de fato quem ela é. Percebe-se então no abandono e cai várias vezes em pranto. É certo que Alice quer uma resposta dos outros sobre sua identidade. Mas apenas isto não Ihe basta. Ela quer também aceitar a si mesma e impõe que somente neste caso - ou seja, "se gostar de ser a tal pessoa" - voltará à superfície. Com esses conflitos ela se debate várias vezes, tal como em um de seus encontros com o Coelho Branco, quando se vê às voltas com sua memória, tentando recordar seus conhecimentos escolares para saber "se ela é ela mesma". Conforme a narrativa, parte da cena assim se passa:

Tenho certeza de que as palavras não são essas - disse a pobre Alice, e as lágrimas inundaram os seus olhos outra vez.

- Devo ter me transformado mesmo em Mabel, e vou ter de viver naquela casa tão pequena, sem brinquedos e, oh, meu Deus, com tanta coisa pra aprender! Não, já resolvi: se eu sou Mabel, então vou ficar aqui embaixo mesmo! Não adianta botarem a cabeça e pedirem: "Suba outra vez, querida!" Só vou levantar a cabeça e dizer: "Quem é que eu sou? Digam primeiro, e se eu gostar de ser a tal pessoa, então subo. Se não, fico aqui embaixo mesmo até que eu seja outra pessoa..." Mas, oh, meu Deus! - gritou, explodindo de repente em lágrimas. (Idem, p. 49)

Lembrar aqui os paradoxos da identidade, tal como expostos na obra de $\mathrm{Carrol}^{8}$, ainda que possa significar uma espécie de digressão, constitui recurso oportuno para sublinhar a complexidade da questão que nos ocupa. Abordar o tema da identidade implica necessariamente falar do eu, bem como das formas 
pelas quais o sujeito rememora suas experiências e entra em contato consigo mesmo. Mas como se acercar disso, se, especialmente nas narrativas autobiográficas, os limites entre realidade e fantasia e entre memória e pensamento são tão tênues e indefinidos? $\mathrm{E}$ parece praticamente impossível separar a memória do sujeito daquilo que constitui a memória dos outros? Em nosso caso particular, trata-se de saber de que modo os docentes realizam essa experiência quando se voltam para si mesmos e se perguntam como se tornaram professores. E, ao fazê-lo, têm que enfrentar a questão de saber se gostam ou não daquilo que fazem. E, mais do que isto, se gostam de ser "esse profissional".

As narrativas autobiográficas são formas privilegiadas para a apreensão de tais processos, ainda que sua escrita envolva um complexo trabalho de elaboração e de rememoração e não permita supor que o euseja uma entidade simplesmente lembrada? . Em seu artigo "The 'remembered' self", Jerome Bruner afirma que mais do que um produto de lembranças o eu é um produto do pensamento, é um "complexo edifício mental que se constrói pelo uso de uma variedade de processos mentais" ( I994, p. 4I). Craig Barclay também discute e problematiza a mesma questão, mas sob outro ângulo. Para ele, o eu é um conceito abstrato. O que existe é uma variedade de eus que emergem pela rememoração produtiva e sua interação (também produtiva) que têm lugar na vida cotidiana. Tais eus lembrados são, desse modo, "parte de nossa experiência fenomênica como indivíduos, formada e compartilhada nas relações interpessoais" (1994, p. 55). É dentro de tais contextos, e especialmente pela narração, que os eus lembrados são construídos e reconstruídos. É no âmbito dessas discussões que Barclay ressalta o caráter adaptativo das memórias autobiográficas, ponderando que as memórias pessoalmente significantes são aquelas que carregam significados adquiridos em seus usos adaptativos, na maior parte das vezes, nas relações com os outros.

Os outros são, dessa forma, referências imprescindíveis das nossas lembranças. Mas não apenas isso. Ao atuarem como espelhos, suas lembranças são por nós apropriadas, tornando-se elementos integrantes e inseparáveis de nossas próprias memórias. Alice, para se certificar sobre si mesma, recorre não apenas a sua memória mas também ao testemunho dos outros. "Quem é que eu sou?", pergunta ela lá do fundo do poço. "Digam primeiro (...). Senão, fico aqui embaixo

8. Para maior aprofundamento deste tema podem-se consultar as referências bibliográficas apresentadas por Sebastião Uchoa Leite (1980) ao final de seu texto "O que a tartaruga disse a Lewis Carrol".

9. Embora não faça parte dos propósitos deste trabalho discutir o tema da ficção autobiográfica, é importante dizer que em certa medida as polêmicas que cercam a questão encontram-se subjacentes às considerações aqui apresentadas. Entre os numerosos trabalhos que hoje já existem sobre o tema, gostaríamos de indicar a obra de Mark Freeman ( 1993) e não poderíamos deixar de mencionar Philippe Lejeune (1975, 1986). 
mesmo até que eu seja outra pessoa..." É quando de sua boca salta o paradoxo e ela se vê desprotegida. Como pode ela mesma vir a ser outra pessoa? Seu choro não seria um sintoma da ameaça da perda de identidade?

Recursos semelhantes também foram utilizados pelas professoras para escreverem seus relatos. Muitas delas confessaram ter enfrentado enormes dificuldades para se lembrar de seus primeiros anos e das primeiras experiências escolares. Tudo parecia ter-se apagado e em alguns casos, com grande esforço, apenas umas poucas lembranças ameaçavam despontar. Tanto em um como em outro caso, elas recorreram a várias pessoas: pais, irmãos, parentes e até amigos. Muitas também se debateram em conflitos com "os outros", por vezes, também caindo em prantos. Passagens da história de uma das professoras são exemplares a esse respeito. Ao final de seu primeiro relato ela singelamente diz: "Escrevi com a ajuda de mamãe e de minha irmã que me avivaram as lembranças". $\bigcirc$ interessante a observar é que ela se apropriou de tais lembranças, assumindo-as como sendo suas. Seu texto não distingue o que ela teria conseguido lembrar por si mesma e quais lembranças foram trazidas pela mãe e pela irmã. Tal exemplo vem corroborar a idéia de que as imagens que o sujeito faz sobre si mesmo no processo de construção de sua identidade são em grande parte fundamentadas nas histórias que lhe são narradas pelos outros. "Nossas histórias", afirma Mark Freeman (1993), "começam não na memória, mas nas histórias contadas a nós pelos outros. Estas se tornam, de fato, nossos passados".

Nesse sentido, o estímulo à construção de narrativas autobiográficas que favoreçam a explicitação das formas pelas quais se vivencia e se concebe a própria história de formação e suas múltiplas relações com as pessoas e os espaços que a conformaram pode constituir um recurso inestimável às reflexões acerca da natureza dos processos formadores e das intervenções que neles se fazem. Decerto uma história das relações com a escola, o conhecimento e os professores pode nos dizer mais sobre a educação e os processos de ensino do que as veleidades prescritivas, ainda hoje estimuladas na produção de conhecimentos ditos pedagógicos. Como se viu, é esse reconhecimento que sustentou a análise aqui mostrada.

\section{REFERÊNCIAS BIBLIOGRÁFICAS}

ALBERT, J.-P. Être soi: écritures ordinaires de l'identité. In: CHAUDRON, M. e SINGLY, F. (orgs.). Identité, lecture, écriture. Paris: Centre Georges Pompidou, Bibliothèque Publique d'Information, 1995, p. 45-58. 
BALL, S. Initial encounters in the classroom and the process of establishment. In: HAMMERSLEY, M., WOODS, P. Life in school: the sociology of pupil culture. Milton Keynes: Open University Press, 1989, p. 108-120.

BARCLAY, C.R. Composing protoselves through improvisation. In: ULRIC, N. e FIVUSH, R. (eds.). The Remembering self: construction and accuracy in the self-narrative. Cambridge: Cambridge University Press, 1994.

BRUNER, J. The "remembered" self. In: ULRIC, N. e FIVUSH, R. (eds.). The Remembering self: Construction and accuracy in the self-narrative. Cambridge: Cambridge University Press, 1994.

BUENO, B.O. Autobiografias e formação de professores: um estudo sobre representações de alunas de um curso de magistério. São Paulo, 1996. Tese (livre doc.) USP.

BUENO, B.O. et al. Docência, memória e gênero: estudos alternativos sobre formação de professores. Psicologia USP, v. 4, n. I/2, p. 299-318, 1993.

CARROLL, L. Aventuras de Alice. 3. ed. São Paulo: Sumus, 1980.

CATANI, D.B. Ensaios sobre a produção e circulação dos saberes pedagógicos. São Paulo, 1994. Tese (livre doc.) USP.

- Memória e biografia: o poder do relato e o relato do poder na história da educação. In: CATANI, D.B. Pesquisa histórica: retratos da educação no Brasil. Rio de Janeiro: Universidade do Estado do Rio de Janeiro, 1995. p. 73-80.

FREEMAN, M. Rewriting the self: history, memory, narrative, London, New York: Routledge, 1993.

GATTAI, Z. Anarquistas, graças a Deus. 4. ed. Rio de Janeiro: Record, 1989.

HAIDAR, M.L.M. O Ensino secundário no Império brasileiro. São Paulo: Grijalbo, 1972.

JOSSO, M. C. Cheminer vers soi. Lausanne: L'Age de L'Homme, 1991.

LEITE, S.U. (trad. e org.) $\bigcirc$ Que a tartaruga disse a Lewis Carrol. 3. ed. In: CARROLL, L. Aventuras de Alice. São Paulo: Sumus, 1980. p. 7-36.

LEJEUNE, P. Le Pacte autobiographique. Paris, Ed. du Seuil, 1975.

. Moi aussi. Paris, Ed. du Seuil, 1986.

NÓVOA, A. Perspectivas de renovação da história da educação em Portugal. In: NÓvOA, A. e BERRIO, J. (eds.) A História da educação em Espanha e Portugal: investigações e actividades. Lisboa: Sociedade Portuguesa de Ciências da Educação, Sociedade Espanhola de Ciências da Educação, 1993, p. I I-22.

NOVOA, A., FINGER, M. (orgs.) O Método (auto)biográfico e a formação. Lisboa: Ministério da Saúde/Departamento de Recursos Humanos/Centro de Formação e Aperfeiçoamento Profissional, 1988. 
PERRONE-MOISÉS, L. O Ateneu, retórica e paixão. São Paulo: Brasiliense, 1988.

PETERS, R.S. Educação como iniciação. In: ARCHAMBAULT, R.D. (orgs.) Educação e análise filosófica. São Paulo: Saraiva, 1979. p. I0I-30.

POMPÉIA, R. OAteneu. São Paulo: Três, 1973.

PONTALLIS, J.B. O Amor dos começos. Rio de Janeiro: Globo, 1988.

RAMOS, G. Infância. 23. ed. Rio de Janeiro, São Paulo: Record, 1986.

RODRIGUES, J.L. Um retrospecto: alguns subsídios para a história pragmática do ensino público em São Paulo. São Paulo: Instituto D. Ana Rosa, 1930.

SOUSA, C.P. et al. Memória e autobiografia: formação de mulheres e formação de professoras. Revista Brasileira de Educação, n. 2, p. 61-76, 1996.

WEBER, S., MITCHEL, C. Using drawings to interrogate professional identity and the popular culture of teaching. In: GOODSON, I. e HARGREAVES, A. (eds.). Teachers' professional lives. London: Falmer Press, 1996. p. 109-26. 